\title{
KARAKTERISTIK KUE PUTRI SALJU MODIFIKASI TEPUNG KACANG KEDELAI (Glycine $\max (L)$ (Merr) DAN TEPUNG BERAS MERAH (Oryza nivara)
}

\author{
Characteristics of Snow Modification of Soya Bean (Glycine Max (L.) (Merr) \\ and Red Rice (Oryza nivara)
}

\author{
Linda Florenta ${ }^{1)}$, Yannie Asrie Widanti ${ }^{1)}$, Nanik Suhartatik ${ }^{1)}$ \\ ${ }^{1)}$ Fakultas Teknologi dan Industri Pangan Universitas Slamet Riyadi Surakarta, \\ Jl. Sumpah Pemuda 18 Joglo Kadipiro Surakarta 57136 \\ Email: lindaflorenta3@gmail.com
}

\begin{abstract}
ABSTRAK
Beras merah merupakan satu produk hasil pertanian yang menyehatkan karena banyak mengandung zat-zat gizi antara lain: mangan, magnesium, serat, dan mempunyai banyak manfaat seperti menghindari diabetes, mencegah penyakit jantung, menurunkan kolesterol, dan meningkatkan HDL Penelitian ini menggunakan metode rancangan acak lengkap (RAL) dengan dua faktor yaitu rasio tepung beras merah, tepung mokaf, dan tepung kacang kedelai (3:4:3), (4:4:2), dan (5:4:1) dan penambahan jenis kacang tanah, kacang mete, dan kacang almond. Hasil penelitian menunjukkan bahwa kombinasi perlakuan rasio tepung beras merah, tepung mokaf, dan tepung kacang kedelai (4:4:2) dan penambahan kacang mete 250 gram menghasilkan kue kering putri salju terbaik dengan kadar air 5,11\%, kadar abu 2,08\% kadar protein 6,47\% kadar lemak $25,56 \%$ gula total $2,81 \%$; dan volume pengembangan $28,08 \%$.
\end{abstract}

Kata kunci: Kue putri salju, substitusi, tepung beras merah, tepung kacang kedelai

\begin{abstract}
Red rice was a healthy products because it contains many nutrients such as manganese, magnesium, fiber and has many benefits such as avoiding diabetes, preventing heart disease, lowering cholesterol, increasing $H D L$. This research was conducted by complete randomized design (RAL) method with three factors: red rice flour ratio: mocaf flour: soybean flour (3:4:3, 4:4:2, 5:4:1), and addition of peanuts, cashews, and almonds. The results showed that the ratio of red rice flour: mocaf flour: soybean flour $(4: 4: 2)$ and the addition of cashews 250 grams was the best "putri salju" cookie that has 5,11\% water content, ash 2,07\%; protein 6,47\%; $25,56 \%$ fat; total sugar $2.81 \%$; and volume development $28,08 \%$.
\end{abstract}

Keywords: Putri salju cookie, substitution, red rice flour, soybean flour.

\section{PENDAHULUAN}

Kue putri salju merupakan kue kering yang diolah dari adonan tepung terigu serta tepung maizena, mentega, dan kuning telur yang kemudian ditaburi dengan gula halus. Dinamakan kue kering putri salju karena butiran gula halusnya nampak menyerupai butiran salju (Kristinemania, 2005). Pada umumnya kue salju dibuat dari tepung terigu. Konsumsi terigu di dalam negeri pada tahun 2012 mencapai 1,22 juta ton dan naik 5,61\% dibandingkan tahun 2011 yang tercacat 1,15 juta (Wahyuni, 2006).

Kacang kedelai dapat dimanfaatkan sebagai bahan baku pembuatan kue putri salju, yaitu dengan cara diolah terlebih dahulu menjadi tepung kacang kedelai agar mudah diproses lebih lanjut menjadi kue putri salju. Kacang Kedelai 90\% digunakan sebagai bahan pangan, 
maka ketersediaan kedelai menjadi faktor yang cukup penting. Kedelai adalah tanaman palawija yang merupakan sumber protein dan kedelai dapat digunakan sebagai penurun kolesterol darah, mencegah penyakit jantung, berfungsi sebagai antioksidan dan dapat mencegah penyakit kanker (Arif, 2009).

Beras merah (Oryza nivara) pengganti gandum dalam pembuatan kue putri salju yang bertujuan mengurangi pemakai gandum yang mencapai 6,3 ton per tahun. Hal ini menunjukan Indonesia sudah sangat banyak mengimpor bahan makan gandum. Tanpa disadari impor gandum dalam jumlah yang banyak ini dapat mengancam stabilitas perekonomian negara, karena harga akan dikendalikan oleh negaranegara produsen. Menurut Departemen Kesehatan RI (1995) beras merah tumbuk mengandung protein $7,3 \%$, besi 4,2 dan vitamin $\mathrm{B} 1 \mathrm{o}, 43 \%$. Berdasarkan kandungan gizinya maka padi beras merah sangat baik untuk daerah rawan pangan khususnya masyarakat.

Jenis kacang-kacangan yang digunakan sebagai bahan tambahan pembuatan kue putri salju selain berpotensi menambah cita rasa, juga dapat meningkatkan kandingan gizi dari kue putri salju yang dihasilkan. Kacang tanah kaya dengan lemak, mengandungi protein yang tinggi, zat besi, vitamin E, kalsium, vitamin B kompleks, fosfor, vitamin A, vitamin K, lesitin, kolin, dan kalsium. Kandungan protein dalam kacang tanah jauh lebih tinggi dari daging, telur, dan kacang soya. Kacang mete termasuk ke dalam jenis kacang-kacangan yang tinggi nutrisi yang baik bagi kesehatan. Kacang mete selain empuk dan lezat juga mengandung energi, antioksidan, mineral, dan vitamin yang penting untuk kesehatan. Kacang almond merupakan sumber nutrisi penting, vitamin, mineral, asam lemak, dan serat makanan yang diperlukan untuk otak dan tubuh yang sehat. Almond juga mengandung vitamin E ekstra, vitamin B kompleks, dan asam lemak omega-3. Kacang almond mengandung banyak nutrisi, antara lain serat pangan, lemak tak jenuh, serta beberapa jenis vitamin B, dan vitamin E. Kacang almond juga memiliki kandungan mineral yang bermanfaat bagi tubuh seperti kalsium, magnesium, zat besi, dan seng.
Adanya peluang dari penggunaan bahan baku tepung beras merah dan tepung dari beberapa jenis kacang-kacangan, maka akan dilakukan penelitian yang berjudul "Karakteristik Kue Putri Salju Modifikasi Tepung Kacang Kedelai (Glycine Max(L) Dan Tepung Beras Merah (Oryza Nivara)". Tujuan dari penelitian ini adalah untuk mengetahui formulasi yang tepat pada proses produksi kue putri salju dan mengetahui sifat kimia kue putri salju dengan modifikasi tepung kedelai dan tepung beras merah yang memiliki kadar protein tinggi.

\section{METODE PENELITIAN \\ Alat dan Bahan Penelitian}

Penelitian dilaksanakan di Laboratorium Rekayasa Pengolahan Pangan dan Laboratorium Kimia \& Biokimia, Fakultas Teknologi dan Industri Pangan, Universitas Slamet Riyadi Surakarta.

\section{Rancangan Percobaan}

Rancangan percobaan yang digunakan pada penelitian ini adalah Rancangan Acak Lengkap Faktorial dengan dua faktor. Faktor pertama adalah rasio tepung beras merah : tepung mokaf : tepung kedelai ((30:40:30), (40:40:20), dan (50:40:10), dan faktor kedua yaitu jenis kacang (kacang tanah, kacang mete, dan kacang almond).

Penelitian ini melibatkan 9 kombinasi perlakuan, masing-masing perlakuan diulang sebanyak tiga kali. Data yang diperoleh dianalisis dengan uji sidik ragam pada jenjang nyata 0,05. Jika ada beda nyata dilanjutkan uji Tukey untuk mengetahui beda nyata antar perlakuan pada tingkat signifikasi $5 \%$.

\section{Cara Penelitian}

\section{a. Pembuatan Tepung Kacang Kedelai} (Yudi et al., 2015)

Kacang kedelai dicuci terlebih dahulu hingga bersih, lalu direndam selama 9 jam kemudian direbus selama 20 menit. Selanjutnya dikeringkan selama 8 jam menggunakan Cabinet dryer kemudian kacang kedelai dihaluskan, diayak menggunakan mesh 35 . Tepung kacang kedelai siap digunakan. 
b. Pembuatan Tepung Beras Merah (Yustisia, 2013)

Beras merah hanya dihaluskan dan kemudian diayak menggunakan mesh 35 .

\section{c. Pembuatan Karakteristik Kue Putri Salju yang Telah Dimodifikasi (Boga, 2005)}

Bahan tepung beras merah, tepung kacang kedelai, tepung kacang kedelai ditimbang sesuai perlakuan, selanjutnya kuning telur dan mentega, dicampur menggunakan mixer hingga merata atau homogen, kemudian semua jenis tepung dimasukkan dan diaduk atau uleni hingga merata. Kemudian dibentuk menggunakan cetakan, lalu dimasak menggunakan oven selama 30 menit $\left(160^{\circ} \mathrm{C}\right)$.

\section{CARA PENGUMPULAN DATA}

Analisis yang dilakukan dalam penelitian ini yaitu analisis kimia, fisika, mikrobiologi dan analisis uji organoleptik. Analisis kimia fisika terdiri dari: analisis kadar air dengan dengan metode Lowry Folin (Supriadi et al., 1997), analisis kadar protein dengan metode Subagyo (2006), analisis kadar lemak (Mojohnier dan Troy, 1973), analisis kadar gula total dengan metode Nelson-Somogyi (AOAC, 1970), dan analisi kadar abu (Widi, 2007).

\section{HASIL DAN PEMBAHASAN}

\section{A. Analisis Kimia}

Tabel 1. Rangkuman Purata Hasil Analisis Kimia Kue Putri Salju Modifikasi Tepung Kacang Kedelai.

\begin{tabular}{|c|c|c|c|c|c|c|c|c|}
\hline No & $\begin{array}{c}\text { Tepung } \\
\text { Beras Merah } \\
\text { : Mokaf : } \\
\text { Kacang } \\
\text { Kedelai }\end{array}$ & Jenis Kacang & $\begin{array}{c}\text { Kadar } \\
\text { Air } \\
(\%)\end{array}$ & $\begin{array}{c}\text { Kadar } \\
\text { Abu } \\
(\%)\end{array}$ & $\begin{array}{c}\text { Kadar } \\
\text { Protein } \\
(\%)\end{array}$ & $\begin{array}{l}\text { Kadar } \\
\text { Lemak }\end{array}$ & $\begin{array}{l}\text { Gula } \\
\text { Total }\end{array}$ & $\begin{array}{l}\text { Volume } \\
\text { Pengem- } \\
\text { bangan }\end{array}$ \\
\hline 1. & & Kacang Tanah & $4.17^{\mathrm{b}}$ & $2.14^{\mathrm{c}}$ & $9.19^{\mathrm{g}}$ & $29 \cdot 39^{f}$ & $6.75^{f}$ & $14.23^{\mathrm{a}}$ \\
\hline 2. & $3: 4: 3$ & Kacang Mete & $4 \cdot 43^{c}$ & $1.98^{\mathrm{a}}$ & $8.96^{f}$ & $27.12^{\mathrm{c}}$ & $4.88^{c}$ & $20.14^{\mathrm{a}}$ \\
\hline 3. & & Kacang Almond & $4.92 \mathrm{~d}$ & $2.00^{\mathrm{a}}$ & $9 \cdot 54^{\mathrm{h}}$ & $25 \cdot 79^{\mathrm{a}}$ & $8.16^{\mathrm{h}}$ & $18.86^{\mathrm{a}}$ \\
\hline 1. & & Kacang Tanah & $3.61^{\mathrm{a}}$ & $2.24^{d}$ & $6.73^{b}$ & $28.34^{\mathrm{e}}$ & $6.14^{\mathrm{e}}$ & $24 \cdot 35^{\mathrm{a}}$ \\
\hline 2. & $4: 4: 2$ & Kacang Mete & $5.11^{\mathrm{e}}$ & $2.07^{\mathrm{b}}$ & $6.46^{\mathrm{a}}$ & $27.55^{\mathrm{d}}$ & $2.81^{\mathrm{a}}$ & $28.08^{a}$ \\
\hline 3. & & Kacang Almond & $5 \cdot 98^{f}$ & $2.15^{\mathrm{c}}$ & $6.90^{c}$ & $26.65^{\mathrm{b}}$ & $4 \cdot 42^{b}$ & $28.19^{a}$ \\
\hline 1. & & Kacang Tanah & $4 \cdot 48^{c}$ & $2.37^{\mathrm{e}}$ & $7 \cdot 92^{\mathrm{e}}$ & $27.48^{\mathrm{d}}$ & $7,02^{\mathrm{g}}$ & $31.74^{\mathrm{a}}$ \\
\hline 2. & $5: 4: 1$ & Kacang Mete & $5.08^{e}$ & $2.36^{\mathrm{e}}$ & $7 \cdot 57^{\mathrm{d}}$ & $25 \cdot 77^{\mathrm{a}}$ & $6.66^{\mathrm{a}}$ & $23.78^{a}$ \\
\hline 3. & & Kacang Almond & $4.89^{d}$ & $2.49^{\mathrm{f}}$ & $7.89^{e}$ & $25.76^{\mathrm{a}}$ & $1.86^{\mathrm{a}}$ & $26.31^{\mathrm{a}}$ \\
\hline
\end{tabular}

Keterangan:-Angka yang diikuti huruf yang sama menunjukkan berbeda tidak nyata dengan Uji Tukey $5 \%$.

\section{Kadar Air Kue Putri Salju}

Kadar air adalah persentase kandungan air suatu bahan yang dapat dinyatakan berdasarkan berat basah (wet basis) atau berdasarkan berat basah kering (dry basis) kadar air berat basah mempunyai batas maksimum teoritas sebesar $100 \%$. Hasil penelitian menunjukkan bahwa kadar air tertinggi pada kue putri salju yaitu $5.98 \%$ terdapat pada perlakuan rasio tepung berah merah : tepung mokaf : tepung kedelai (4:4:2) dengan penambahan kacang almond 250 gram. Kadar air terendah sebesar 3,62\% diperoleh dari perlakuan rasio tepung beras merah : tepung mokaf : tepung kedelai (4:4:2) dengan penambahan 250 gram kacang tanah.

Menurut Suarni (1999), tepung beras merah mengandung 4,72\% kadar air, tepung kacang kedelai $8,17 \%$, sedangkan tepung mokaf $6,9 \%$ (SNI, 2009). Hasil penelitian menunjukkan bahwa kadar air cenderung meningkat pada penambahan jenis kacang mete. Hal ini ini disebabkan karena kacang mete mengandung kadar air sebesar 4,67\%, sedangkan kacang tanah 3,5\%, dan kacang almond hanya 4,54\%, sehingga menyebabkan semakin meningkatnya kadar air kue putri salju (Suryono, 2010). 
Menurut syarat mutu kue kering dalam SNI No. 01-2973-1992 kadar air kue kering maksimal adalah 5\%, dengan demikian kadar air kue kering dalam penelitian ini masih memenuhi syarat mutu kue kering. Salah satu proses pembuatan kue kering adalah pemanggangan. Menurut Widjanarko (2008), pemanasan akan menyebabkan terjadinya gelatinisasi pati dimana granula pati akan membengkak akibat adanya penyerapan air. Pembengkakan granul pati terbatas hingga 30\% dari berat tepung. Apabila pembengkakan granula pati telah mencapai batas, granula pati tersebut akan pecah sehingga terjadi proses penguapan air.

\section{Kadar Abu Kue Putri Salju}

Kadar abu merupakan campuran dari komponen anorganik atau mineral yang terdapat pada suatu bahan pangan. Bahan pangan terdiri 96\% bahan anorganik dan air, sedangkan sisanya merupakan unsur-unsur mineral. Unsur juga dikenal sebagai zat organik atau kadar abu. Kadar abu tersebut dapat menunjukkan total mineral dalam suatu bahan pangan (Zahro, 2013). Pengukuran kadar abu bertujuan untuk mengetahui besarnya kandungan mineral dalam suatu bahan (Sudarmadji et al., 2003).

Hasil penelitian menunjukkan bahwa kadar abu cenderung menurun dengan penambahan tepung kacang kedelai. Hal ini disebabkan karena tepung kacang kedelai mengandung kadar abu hanya sebesar $0,21 \%$, sedangkan tepung beras merah mengandung kadar abu sebesar 1,2 (Maulinda, 2016), sehingga semakin berkurang penambahan tepung kacang kedelai akan semakin tinggi kadar abu dalam kue putri salju. Berbagai bahan yang berkontribusi terhadap kadar abu kue kering salah satunya kuning telur. Tinggi rendahnya kadar abu suatu bahan antara lain disebabkan oleh kandungan mineral berbeda pada sumber bahan baku dan juga dipengaruhi oleh proses demineralisasi pada saat pembuatan (Rizky, 2013).

\section{Kadar Protein Kue Putri Salju}

Protein merupakan suatu zat makanan yang sangat penting bagi tubuh karena zat ini berfungsi sebagai sumber energi dalam tubuh serta sebagai zat pembangun dan pengatur.
Protein adalah polimer dari asam amino yang dihubungkan dengan ikatan peptide. Molekul protein mengandung unsur-unsur $\mathrm{C}, \mathrm{H}, \mathrm{O}, \mathrm{N}$, $\mathrm{P}, \mathrm{S}$ dan terkadang mengandung unsur logam seperti besi dan tembaga (Winarno, 1992).

Hasil penelitian menunjukkan bahwa kadar protein tertinggi pada kue putri salju yaitu $9.541 \%$ diperoleh dari perlakuan rasio tepung beras merah : tepung mokaf : tepung kacang kedelai (5:4:1) dan konsentrasi kacang almond. Kadar protein terendah sebesar $6.466 \%$ diperoleh dari perlakuan rasio tepung beras merah : tepung mokaf : tepung kacang kedelai (4:4:2) dan konsentrasi kacang mete. Semakin tinggi pemberian kacang mete pada kue kering putrid salju. Pemberian kacang almond berpengaruh pada kadar protein 19,5\% (Purseglove, 1977). Menurut syarat mutu kue kering SNI No. 2973-2011 kadar protein kue kering minimum adalah $5 \%$ (SNI, 2011), dengan demikian protein kue kering penelitian ini belum memenuhi syarat mutu kue kering. Standar mutu kue kering dalam SNI (2011) tersebut adalah kue kering yang beredar di pasaran dan biasanya dibuat dari tepung terigu saja.

\section{Kadar Lemak Kue Putri Salju}

Lemak merupakan bagian dari lipid yang mengandung asam lemak jenuh bersifat padat. Lemak merupakan senyawa organik yang terdapat di alam serta tidak larut dalam air tetapi larut dalam air dan pelarut organik non-polar seperti dietil eter, kloroform, benzene, hexane, dan hidrokarbon lainnya. Terdapat dua jenis lemak yaitu lemak jenuh dan lemak tak jenuh. Lemak jenuh terdapat pada pangan hewani (Makfoeld, 2002).

Hasil penelitian menunjukkan bahwa kadar lemak tertinggi pada kue putri salju yaitu 9.529\% diperoleh dari perlakuan rasio tepung beras merah : tepung mokaf : tepung kacang kedelai dan penambahan kacang tanah. Kadar lemak terendah $6.495 \%$ diperoleh dari perlakuan rasio tepung beras merah : tepung mokaf : tepung kacang kedelai (4:4:1) dan konsentrasi kacang almond. Lemak merupakan komponen paling penting dalam pembuatan kue kering. Di dalam adonan, lemak berfungsi sebagai penambah 
flavor. Lemak yang berlebihan mengakibatkan kue kering akan melebar dan mudah hancur, sedangkan jumlah lemak yang terlalu sedikit membuat tekstur kue kering menjadi keras.

\section{Kadar Gula Total Kue Putri Salju}

Gula total merupakan hidrolisis pati campuran gula reduksi dan non reduksi yang merupakan hasil hidrolisis. Semua monosakarida dan disakarida berperan sebagai pereduksi dan karenanya dikenal sebagai gula reduksi. Kadar gula total adalah kandungan gula keseluruhan dalam suatu bahan pangan (monosakarida maupun oligosakarida).

Hasil penelitian menunjukkan bahwa kadar gula total tertinggi pada kue putri salju yaitu $8,18 \%$ diperoleh dari perlakuan rasio tepung beras merah : tepung mokaf : tepung kacang kedelai (3:4:3) dan konsentrasi kacang tanah. Sedangkan kadar gula total terendah sebesar 2.81\% diperoleh dari perlakuan rasio tepung beras merah : tepung mokaf : tepung kacang kedelai (4:4:2) dan konsentrasi kacang mete. Tabel 1 menunjukkan bahwa kadar gula total cenderung menurun seiring dengan semakin meningkatnya tepung beras merah.

\section{Volume Pengembangan}

Komponen utama dalam tepung yang berpengaruh terhadap tekstur adalah protein. Protein yang terdapat dalam terigu dapat membentuk gluten bila ditambah air. Gluten adalah campuran amorf (bentuk tak beraturan) dari protein yang terkandung bersama pati dan endosperm. Apabila jumlah gluten dalam adonan sedikit menyebabkan adonan kurang mampu menahan gas, sehingga pori-pori yang terbentuk dalam adonan juga kecil-kecil. Sehingga gluten dapat menyebabkan adonan bersifat elastis dan mampu menahan gas dan akibatnya adonan tidak mengembang dengan baik (Handayani, 1987).

Hasil penelitian menunjukkan bahwa volume pengembangan tertinggi pada kue putri salju yaitu 31,74\% diperoleh dari perlakuan rasio tepung beras merah : tepung mokaf : tepung kacang kedelai (5:4:1) dan konsentrasi kacang tanah. Sedangkan kadar gula total terendah sebesar 14,23\% diperoleh dari perlakuan rasio tepung beras merah : tepung mokaf : tepung kacang kedelai (3:4:3) dan konsentrasi kacang tanah.

\section{B. Hasil Uji Organoleptik}

Tabel 2. Rangkuman Purata Hasil Uji Organoleptik Kue Putri Salju Modifikasi Tepung Kacang Kedelai.

\begin{tabular}{|c|c|c|c|c|c|c|c|}
\hline No & $\begin{array}{c}\text { Tepung Beras } \\
\text { Merah : Mokaf : } \\
\text { Kacang Kedelai }\end{array}$ & Jenis Kacang & Warna & Tekstur & $\begin{array}{l}\text { Flavor } \\
\text { Tepung } \\
\text { Beras } \\
\text { Merah }\end{array}$ & $\begin{array}{l}\text { Flavor } \\
\text { Kacang } \\
\text { Kedelai }\end{array}$ & $\begin{array}{l}\text { Kesukaan } \\
\text { Keseluruhan }\end{array}$ \\
\hline 1. & & Kacang Tanah & $2.06^{\mathrm{a}}$ & $2.40^{\mathrm{a}}$ & $2.20^{\mathrm{a}}$ & $1.93^{\mathrm{a}}$ & $2.26^{a}$ \\
\hline $\begin{array}{l}2 . \\
3 .\end{array}$ & $3: 4: 3$ & $\begin{array}{l}\text { Kacang Mete } \\
\text { Kacang Almond }\end{array}$ & $\begin{array}{l}1.66^{\mathrm{a}} \\
2.00^{\mathrm{a}}\end{array}$ & $\begin{array}{l}3 \cdot 33^{\mathrm{c}} \\
3 \cdot 00^{\mathrm{b}}\end{array}$ & $\begin{array}{l}2.00^{\mathrm{a}} \\
1.93^{\mathrm{a}}\end{array}$ & $\begin{array}{l}2.80^{\mathrm{a}} \\
2.26^{\mathrm{a}} \\
\end{array}$ & $\begin{array}{l}2.46^{\mathrm{a}} \\
2.13^{\mathrm{a}}\end{array}$ \\
\hline $\begin{array}{l}1 . \\
2 . \\
3 .\end{array}$ & $4: 4: 2$ & $\begin{array}{l}\text { Kacang Tanah } \\
\text { Kacang Mete } \\
\text { Kacang Almond }\end{array}$ & $\begin{array}{l}2.00^{\mathrm{a}} \\
1.53^{\mathrm{a}} \\
2.00^{\mathrm{a}}\end{array}$ & $\begin{array}{l}2.93^{\mathrm{b}} \\
2.93^{\mathrm{b}} \\
2.46^{\mathrm{a}}\end{array}$ & $\begin{array}{l}1.60^{\mathrm{a}} \\
2.00^{\mathrm{a}} \\
2.06^{\mathrm{a}}\end{array}$ & $\begin{array}{l}2.00^{\mathrm{a}} \\
2.73^{\mathrm{a}} \\
2.13^{\mathrm{a}}\end{array}$ & $\begin{array}{l}2.13^{\mathrm{a}} \\
2.60^{\mathrm{a}} \\
2.33^{\mathrm{a}}\end{array}$ \\
\hline $\begin{array}{l}1 . \\
2 . \\
3 .\end{array}$ & $5: 4: 1$ & $\begin{array}{l}\text { Kacang Tanah } \\
\text { Kacang Mete } \\
\text { Kacang Almond }\end{array}$ & $\begin{array}{l}2.00^{\mathrm{a}} \\
1.66^{\mathrm{a}} \\
1.86^{\mathrm{a}}\end{array}$ & $\begin{array}{l}2.00^{\mathrm{a}} \\
2.93 \\
2.20\end{array}$ & $\begin{array}{l}1.53^{\mathrm{a}} \\
2.40^{\mathrm{b}} \\
2.60^{\mathrm{b}}\end{array}$ & $\begin{array}{l}2.73^{\mathrm{a}} \\
2.80^{\mathrm{a}} \\
2.26^{\mathrm{a}}\end{array}$ & $\begin{array}{l}2.40^{\mathrm{a}} \\
2.60^{\mathrm{a}} \\
2.40^{\mathrm{a}}\end{array}$ \\
\hline
\end{tabular}

Keterangan:

1. Warna Kue : : Angka tertinggi menunjukkan warna sangat coklat.

2. Rasa Kacang Kedelai : Angka tertinggi menunjukkan rasa/aroma kacang kedelai semakin terasa.

3. Kesukaan Keseluruan : Angka tertinggi menunjukan panelis semakin suka.

4. Tekstur : : Angka semakin tinggi menunjukan tekstur semakin kasar. 


\section{Warna Kue Putri Salju}

Warna memegang peranan penting dalam penerimaan makanan, selain itu warna dapat memberi petunjuk mengenai perubahan kimia dalam makanan. Menurut Kartika et al. (1988), warna merupakan sifat bahan yang dianggap berasal dari penyebaran spektram sinar. Selain itu warna merupakan suatu sensasi seseorang oleh karena adanya rangsangan dari seberkas energi radiasi yang jatuh ke indra mata atau retina mata. Kesukaan terhadap warna merupakan penilaian pertama yang akan menentukan kesukaan panelis terhadap produk kue kering.

Hasil penelitian menunjukkan bahwa warna tertinggi pada kue putri salju yaitu $(2,06)$ diperoleh dari perlakuan rasio tepung beras merah : tepung mokaf : tepung kacang kedelai (3:4:3) dan konsentrasi kacang tanah, sedangkan warna terendah sebesar $(1,53)$ diperoleh dari perlakuan rasio tepung beras merah : tepung mokaf : tepung kacang kedelai (4:4:2) dan konsentrasi kacang mete.

\section{Tekstur Kue Putri Salju}

Tekstur adalah salah satu sifat bahan atau produk yang dapat dirasakan melalui sentuhan kulit ataupun pencicipan dalam kue putri salju mempunyai tekstur sedikit kasar karena terdapat kacang yaitu kacang tanah, kacang mete, dan kacang almond. Tekstur menjadi bagian yang penting dalam bahan makanan dan hasil pertanian, karena tekstur menjadi bagian yang penting dalam bahan makanan dan hasil pertanian. Pengukuran tekstur telah menjadi salah satu faktor terpenting dalam industri pangan, khususnya sebagai indikator dari aspek non visual (Abbot dan Haiker, 2005).

Hasil penelitian menunjukkan bahwa tekstur tertinggi pada kue putri salju yaitu $(3,33)$ diperoleh dari perlakuan rasio tepung beras merah : tepung mokaf : tepung kacang kedelai (3:4:3) dan konsentrasi kacang mete. Sedangkan tekstur terendah sebesar $(1,53)$ diperoleh dari perlakuan rasio tepung beras merah : tepung mokaf : tepung kacang kedelai (5:4:1) dan konsentrasi kacang tanah.

\section{Flavor Tepung Beras Merah}

Menurut Kartika et.al (1988), ada 2 cara dalam mengamati flaovor yaitu pertama melalui indera pembau, dimana rangsangan akan diterima oleh region alfactoria yaitu suatu bagian pada atas rangga hidung, yang kedua biasa lewat mulut bagi yang sukar mengamati lewat hidung. Hasil analisis sidik ragam menunjukkan bahwa flavor tepung beras merah pada kue putri salju pada perlakuan konsentrasi penambahan tepung beras merah berbeda tidak nyata.

Hasil penelitian menunjukkan bahwa flavor tepung beras merah tertinggi pada kue putri salju yaitu $(2,60)$ diperoleh dari perlakuan rasio tepung beras merah : tepung mokaf : tepung kacang kedelai (5:4:1) dan konsentrasi kacang almond. Sedangkan flavor beras meras kue putri salju terendah sebesar $(1,53)$ diperoleh dari perlakuan rasio tepung beras merah : tepung mokaf : tepung kacang kedelai (5:4:1) dan konsentrasi kacang tanah.

\section{Flavor Tepung Kacang Kedelai}

Hasil penelitian menunjukkan bahwa flavor tepung kacang kedelai tertinggi pada kue putri salju yaitu $(2,80)$ diperoleh dari perlakuan rasio tepung beras merah : tepung mokaf : tepung kacang kedelai dengan perbandingan (3:4:3) dan (5:4:1) dan konsentrasi kacang mete. Sedangkan flavor tepung kacang kedelai kue putri salju terendah sebesar $(1,93)$ diperoleh dari perlakuan rasio tepung beras merah : tepung mokaf : tepung kacang kedelai (3:4:3) dan konsentrasi kacang tanah.

\section{Kesukaan Keseluruhan}

Kesukaan dan penerimaan konsumen terhadap suatu bahan mungkin tidak hanya dipengaruhi oleh satu faktor, akan tetapi dipengaruhi oleh berbagai macam faktor, akan tetapi dipengaruhi oleh berbagai macam faktor sehingga menimbulkan penerimaan yang utuh. Atribut keseluruhan ini hampir sama dengan penampakan suatu produk secara kesekuruhan, yang berfungsi yaitum mengetahui tingkat penerimaan konsumen. Hasil penerimaan panelis terhadap kue putri salju dipengaruhi oleh kesukaan penelis terhadap warna, rasa, 
aroma, dan kerenyahan putri salju.

Hasil penelitian menunjukkan bahwa kesukaan keseluruhan panelis terhadap kue putri salju tertinggi pada kue putri salju yaitu $(2,60)$ diperoleh dari perlakuan rasio tepung beras merah : tepung mokaf : tepung kacang kedelai dengan perbandingan (4:4:2) dan (5:4:1) dan konsentrasi kacang mete. Sedangkan kesukaan keseluruhan panelis terhadap kue putri salju terendah sebesar $(1,93)$ diperoleh dari perlakuan rasio tepung beras merah : tepung mokaf : tepung kacang kedelai dengan perbandingan (3:4:3) dan konsentrasi kacang almond serta perlakuan rasio tepung beras merah : tepung mokaf : tepung kacang kedelai dengan perbandingan (5:4:1) dan konsentrasi kacang tanah.

\section{KESIMPULAN DAN SARAN}

\section{A. KESIMPULAN}

- Tepung beras merah dan tepung kacang kedelai dapat digunakan subtitusi tepung mokaf pada pembuatan kue putri salju.

- Kombinasi perlakuan yang dipilih adalah rasio tepung beras meras : tepung mokaf : tepung kacang kedelai (4:4:2) dengan penambahan kacang mete akan menghasilkan kue putri salju berkualitas yang bagus.

- Karakteristik kue putri salju sisebut di atas adalah memiliki kadar air (5,11\%), kadar abu (2,0765\%), kadar gula total $(2,8101)$, volume pengembangan $(1,08)$, warna $(1,53)$, tekstur $(2,93)$, flavor tepung beras merah $(2,00)$, flavor tepung kacang kedelai $(2,73)$, dan kesukaan keseluruhan $(2,60)$.

\section{B. SARAN}

- Perlu dilakukan penelitian lebih lanjut mengenaiumursimpankueputrisalju.

- Perlu dilakukan penelitian subtitusi tepung mocaf dengan menggunakan tepung lain non gluten yang belum bnyak dimanfaatkan untuk pembuatan kue putri salju.

\section{DAFTAR PUSTAKA}

Badan Standarisasi Nasional, 1992. Cara Uji Makanan Dan Minuman. SNI 01-2981-
1992. Jakarta.

Boga, Y., 2005. Bolu Dan Kue. Jakarta: Gramedia Pustaka.

Bennio, M., 1975. Introduction Foods, 6th Edition. London: Applied Science Publishers Ltd.

Dewi, S. R., 2013. Penggunaan Ekstrak Biji Buah Alpukat (Persea Americana Mill.) Sebagai Antibakteri Proteus Mirabilis Dan Aerobacter Aerogenes. Jakarta Gramedia.

Faridah., 2008. Patiseri Jilid I Untuk SMK. Jakarta: Departemen Pendidikan Nasional.

Gardjito, M., 2009. Pengelolaan Pangandan Gizi. Yogyakarta: Pusat Kajian Makanan Tradisional Universitas Gadjah Mada.

Kristinemania, 2005. Karakteristik Kue Putri Salju. Jakarta: Gramedia.

Purnomo, H., 1987. Bahan Tambahan Pangan. Yogyakarta: Publising Company Inc.

Putri, L. C., 2017. Pemanfaatan Bekatul Beras Merah dan Penambahan Jahe Merah Dalam Pembuatan Biskuit Fungsional. Skripsi. Surakarta: Fakultas Teknologi Dan Industri Pangan Universitas Slamet Riyadi.

Rismuhandar dan Farry, B., 2001. Kayu Manis Budidaya dan Pengolahan. Jakarta: Penebar Swadaya.

Rizky, A., Fatimah, N., dan Elok, M., 2013. Ekstraksi Gelatin dari Tulang Ikan Tenggiri Melalui Proses Hidrolisis Menggunakan Larutan Basa. Jurnal Media Farmasi (10):18-28.

Salim, P, S., 2012. Pengoptimalan Persediaan Bahan Baku Kacang Tanah Menggunakan Metode EOQ (Economic Order Quantity) di PT. Dua Kelinci Pati. Skripsi. Fakultas Pertanian Universitas Sebela.

Samuel, 1972. Proses Pemagangan Kue Kering PT. Gramedia Pustakautama.

Saputro, M., dan Agung, P., 2015. Pembuatan Bubuk Cabai Rawit (Kajian Konsentrasi Kalsium Propionat dan Lama Waktu Perebusan Terhadap Kualitas Produk). Prosiding Seminar Nasional. Bahan Pangan Yogyakarta.

Setiavani, G., 2008. Teknologi Pengolahan Cabe Merah. Jakarta: Gramedia.

Smith, W. H., 1973. Biscuit Crackers and Cookies. 
London: Applied Science Publisher Ltd Vol. 1.

Suarni, 200o. Studi Pembuatan Kue Kering (Cookies) Dari Tepung Sebagai Bahan Alternatif Subtitusi Terigu. Prosiding Seminar Nasional. Bali.

Suarni, 2010. Studi Pembuatan Kue Kering (Cookies) Dari Tepung Sebagai Bahan Alternatif Subtitusi Terip: Bali Prosiding. Seminar.Nasional.

Subagyo, 2006. Pengembangan Tepung Ubi Kayu Sebagai Bahan Industri Pangan. Seminar Rusnas Diversifikasi Pangan Pokok Industrialisasi Diversifikasi Pangan Berbasis Potensi Pangan Lokal. Kementrian Ristek dan Seafast Center. Bogor: Institut Pertanian Bogor.

Sudarmadji., Haryono, B., dan Suhardi., 2003. Analisa Bahan Makanan dan Pertanian. Yogyakarta: Kanisius.

Sudarmadji, S., Suhardi., dan Haryono, B., 1989. Analisa Bahan Makanan dan Pertanian. Yogyakarta: Kanisius.

Sudarmadji, S.. Haryono, B., dan Suhardi., 2003. Analisa Bahan Makanan dan Pertanian. Yogyakarta: Liberty.

Sundari, E., 2011. Pengambilan Minyak Atsiri dan Oleoresin Dari Kulit Kayu Manis. ITB Central Library. Bandung: Ganesha.

Supriyadi, 2006. Optimalisasi Pertumbuhan dan Hasil Tanaman Gandum (Triticum Aestivum L.) Genotipe So-8 Melalui Pemberian Pupuk Kotoran Gandum Di Alahan Panjang Kabupaten Solok: Trubus Agrisarana.

Suryani, A., dan Santoso., 2006. Bisnis Kue Kering. Jakarta: Jakarta Penebar Swadaya.

Suryono, 2010. Kadar Air Dalam Kue Kering. Jakarta: Kriya Pustaka London. Applied Science Publisher Ltd Vol. 1.

Sutomo, B., 2008. Sukses Wirausaha Kue Kering. Jakarta: Kriya Pustaka.

Sutomo, B., 2012. Rahasia Sukses Membuat Cake, Roti, Kue Kering \& Jajan Pasar. Jakarta: Kriya Pustaka.

Syarief, R., dan A. Irawati., 1988. Pengetahuan Bahan Untuk Industri Pertanian. Jakarta: PT. Mediyatama Sarana Prakasa.

Tarwotjo dan Soejuti., 2004. Dasar-Dasar Gizi
Kuliner. Jakarta: Jakarta Gramedia.

Wahyuni, 2006. Hasil Konsumsi Terigu Dalam Negeri. Jakarta: Departemen Perindustrian.

Wahyuningsih, S. B., 1990. Pengaruh Lama Fermentasi dan Cara Pengeringan Terhadap Mutu Gari yang Dihasilkan. Skripsi: Bogor: Fakultas Teknologi Pertanian, Institut Pertanian Bogor.

Wahyuningsih, S. B., 2009. Kajian Mutu Tepung Mocaf (Modified Cassava Flour) yang Dibuat Dengan Berbagai Metode, Aplikasinya Untuk Mie Kering dan Analisis Ekonominya. Laporan Akhir Kegiatan Fasilitasi Pelaksanaan Riset Unggulan Daerah. Semarang: Lembaga Penelitian dan Pengabdian Masyarakat. Universitas Semarang.

Widi, 2007. Cara Pengolahan Mokaf. Bogor: Biro Penataran Institut Pertanian Bogor.

Widjanarko, 2008. Proses Pembuatan Kue Kering Prosiding Seminar Nasional. Bali. Widodo, P., 200o. Pemanfaatan Jahe Secara Optimal. Jakarta: Jakarta Gramedia.

Wijaya, W., 2005. Pembuatan Sakko-Sakko Dari Tepung Kacang Kedelai. Pasca Sarjana Universitas Hasanudin.

Wijayanti, I., 2015. Eksperimen Pembuatan Kue Semprit Tepung Beras Merah. Skripsi. Semarang: Universitas Negeri Semarang. Winarno, F. G., 1992. Pengantar Teknologi Pangan. Jakarta: Gramedia.

Winarno, F. G., 2002. Kimia Pangan dan Gizi. Jakarta: PT. Gramedia Pustakautama.

Winarno, F. G., 2004.Keamanan Pangan Jilid 1. Bogor: M-Brio Press.

Winarno, F. G.,1989. Gluten Dalam Ensiklopedia Nasional Indonesia. Jilid 6. Jakarta: PT Cipta Adi Pustaka.

Wiraswati, A. 2013. Pengaruh Subtitusi Tepung Mocaf (Modified Cassava Flour) Terhadap Mutu Organoleptik Kue Mochi. Jurnal Tata Boga (3): 44-50.

Yanik, 2009. Komposisi Cizi Dalam Kacang Mete. Skripsi. Semarang: Universitas Negeri Semarang.

Yudi, 2007 Komposisi Kimia Kacang Almond. Pengetahuan Bahan Untuk Industri Pertanian. Jakarta: PT. Mediyatama 
Sarana Prakasa.

Yustisia, R., 2013. Pengaruh Penambahan Telur Terhadap Kadar Protein, Serat, Tingkat Kekenyalan dan Penerimaan Mie Basah Bebas Gluten Berbahan Baku Tepung Komposit (Tepung Komposit: Tepung
Mocaf, Tapioka, dan Maizena). Journal Off Nutritioncollage (4): 697-703.

Zahro, 2013 Total Mineral Dalam Suatu Banhan Pangan. Applied Science Publisher Ltd. Vol. 1. 